
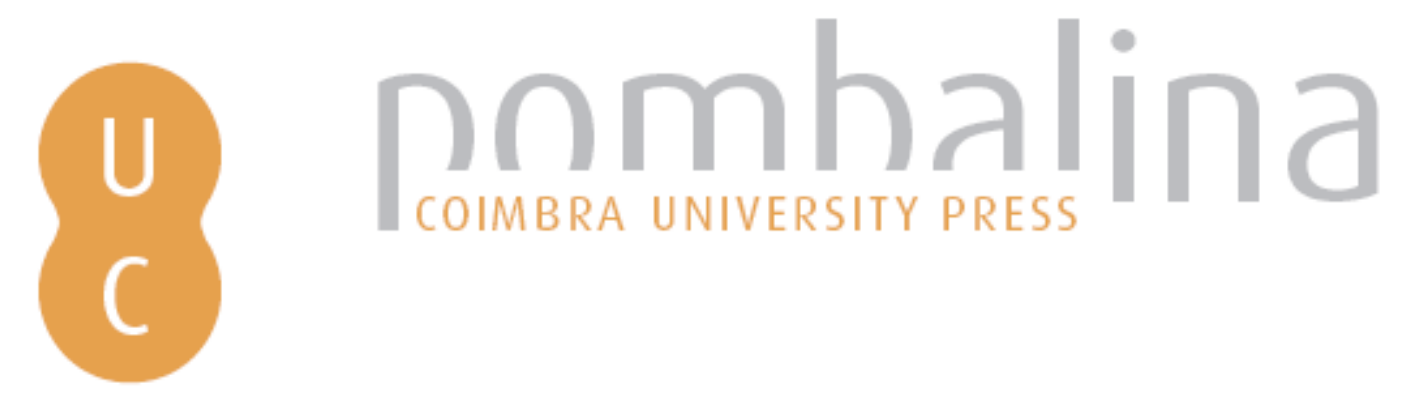

FMECA analysis for the assessing of maintenance activity for power transformers

$\begin{array}{ll}\text { Autor(es): } & \text { Khalil, Mohamed Mahmoud Abdel Fattah; Cristaldi, Loredana; Faifer, } \\ \text { Marco } & \end{array}$

Publicado por: Imprensa da Universidade de Coimbra

URL

persistente: URI:http://hdl.handle.net/10316.2/33313

DOI: $\quad$ DOI:http://dx.doi.org/10.14195/978-972-8954-42-0_4

Accessed : $\quad$ 26-Apr-2023 11:31:25

A navegação consulta e descarregamento dos títulos inseridos nas Bibliotecas Digitais UC Digitalis, UC Pombalina e UC Impactum, pressupõem a aceitação plena e sem reservas dos Termos e Condições de Uso destas Bibliotecas Digitais, disponíveis em https://digitalis.uc.pt/pt-pt/termos.

Conforme exposto nos referidos Termos e Condições de Uso, o descarregamento de títulos de acesso restrito requer uma licença válida de autorização devendo o utilizador aceder ao(s) documento(s) a partir de um endereço de IP da instituição detentora da supramencionada licença.

Ao utilizador é apenas permitido o descarregamento para uso pessoal, pelo que o emprego do(s) título(s) descarregado(s) para outro fim, designadamente comercial, carece de autorização do respetivo autor ou editor da obra.

Na medida em que todas as obras da UC Digitalis se encontram protegidas pelo Código do Direito de Autor e Direitos Conexos e demais legislação aplicável, toda a cópia, parcial ou total, deste documento, nos casos em que é legalmente admitida, deverá conter ou fazer-se acompanhar por este aviso.

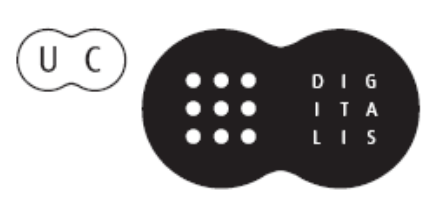




\title{
FMECA Analysis for the Assessing of Maintenance Activity for Power Transformers
}

\author{
Mohamed Mahmoud Abdel Fattah Khali1 ${ }^{1}$; Loredana Cristaldi ${ }^{2}$; Marco Faifer ${ }^{3}$ \\ 1․mohamedmahmoud.khalil@polimi.it; ${ }^{2}$ loredana.cristaldi@polimi.it; ${ }^{3} \underline{\text { marco.faifer@polimi.it }}$ \\ 1,2,3 DEIB -Politecnico di Milano \\ Milano, Italy
}

\begin{abstract}
A serious failure of a large power transformer can generate substantial costs for the transport to factory, repair and financial losses resulting from power interruption. Therefore, utilities have a clear incentive to assess the actual condition of high voltage transformers, with the aim to minimize the risk of failures and avoid forced unexpected outages. Special attention in this respect is given to large transformers. In this paper, a general FMECA for outage causes of $220 \mathrm{kV}$ power transformers is presented, including the local and final effects, and recommended actions to avoid these outages. Assignment of risk priority numbers to the various outage causes, which might occur at this voltage level, are carefully considered.
\end{abstract}

\section{Keywords-Transformer Failures, FMECA.}

\section{INTRODUCTION}

According to ANSI/IEEE C57.117-1986 [1], a transformer is a static electric device consisting of a winding or two, or more coupled windings, with a magnetic core for introducing mutual coupling between electric circuits through electromagnetic induction.

The transformer includes all transformer-related components, such as bushings, load tap changers, fans, temperature gauges, etc., and excludes all system-related components (e.g. surge arresters, grounding resistors, highvoltage switches, low-voltage switches and house service equipment).

Transformers can be classified into many types such as power transformers, autotransformers, regulating transformers, etc. Based on their application, transformers are classified into substation transformers, transmission tie transformers, unit transformers, etc. The study reported in this paper considers 220 $\mathrm{kV}$ power transformers for utility applications.

Transformers have a key role in power systems and their reliability directly affects the reliability of the whole network. Outage of transformers is considered a failure, since it is an event that determines a fault state (the transformer cannot perform its specified function) [1].

Generally, transformer outages are either forced or scheduled, and both are done by means of switching operations. Forced outages of transformers are mainly due to automatic switching operations performed by protection systems [2], [3], [4]. They are caused by either external (such as transmission line faults) or internal causes (such as core failure and winding failure). In [3] and [4] more details about failure statistics of transformer subassemblies are given. For the purpose of abbreviation in this paper, the term 'outage' will refer to 'forced outage'.

Transformers outages are classified according to their operating voltage level in the network. In this paper the $220 \mathrm{kV}$ voltage level was selected, because it is considered one of the oldest transmission networks in many European countries[5], [6]. For instance, the generation plants in Germany are linked to the unified Grid through $220 \mathrm{kV}$ level [7]. In both Romania and Switzerland, the $220 \mathrm{kV}$ system is considered the backbone of transmission network [8],[9].

Since large groups of transformers operating in the world have already exceeded 30-year exploitation period [25], in the literature several surveys highlighting the outage causes of transformers can be found. A ten years survey by a CIGRÉ working group, on internal failures in large substation utility transformers [2] pointed out that about $41 \%$ of failures were due to on-load tap changers (OLTC) and about $19 \%$ were due to the windings. The number of transformers, under investigation, with on load tap changer was 15786 unityears and voltage level ranges from $100 \mathrm{kV}$ to $300 \mathrm{kV}$. The total numbers of failures were 370 during the study period 1968-1978. Fig. 1 shows the percentage failure distribution for power transformers with onload tap changers [2].

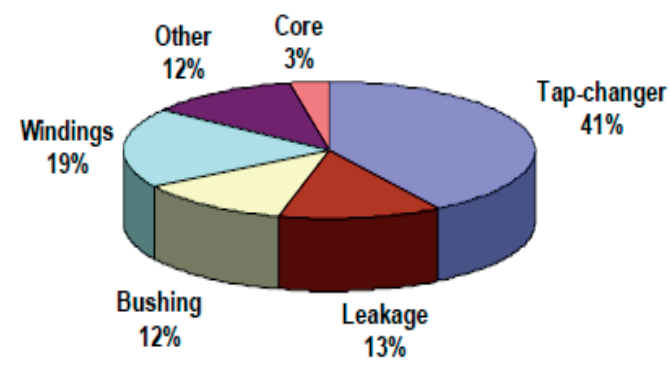

Fig. 1. Percentage failure of power transformers (CIGRE survey).

Transformer internal failure data analysis in South Africa in the period 1985-1995 is presented in [3]. The failure analysis was based on 188 outages of transformers with a rated voltage ranging from $88 \mathrm{kV}$ to $765 \mathrm{kV}$ and rated power from 20 to 800 MVA. Considering 100-400MVA transformers, the total number of failures for general ageing, core problems, lighting/switching, others, short circuit, and tap changers were $15,8,2,15,1$, and 5 respectively. In 2006 this investigation was extended for units failing in the period 1996 to 2006, and was based on failure study of step-up generator, transmission and 
distribution transformer failures. Bushings, tap changers and windings represent about $79 \%$ of outage causes during this study period. The contribution of core related failures was $2 \%$ only [4].

Another study was done on 50 outages of 500 transformers with rated power ranging from 14MVA to 175 MVA [19]. Tap changer and bushing failure were the dominant causes of outage for transformers having a rated voltage ranging from 110 to 150 $\mathrm{kV}$. In [20] the failure statistics of transformers in Thailand was studied by considering the scattering of history data. The data were collected from 44 transformers with rated voltage of 230/115/22 kV with total 68 minor failures. The failure statistical analysis shows that other failure was the highest, $41.3 \%$, followed by bushing, $31.7 \%$, tap changer, $17.5 \%$, leakage $7.9 \%$ and winding $1.6 \%$. Outage data analysis for power transformers in Egypt over the period 2002-2009 is presented in [21], [22], [23], [9].

TABLE I. TRANSFORMERS OUTAGE CAUSES

\begin{tabular}{|c|c|c|}
\hline Failure & \multicolumn{2}{|c|}{ Outage Cause } \\
\hline \multirow{5}{*}{$\stackrel{\grave{\Xi}}{\dot{\Xi}}$} & Outage category & \\
\hline & Electrical outage & $\begin{array}{ll}\text { - } & \text { Buchholz \& Pressure relief } \\
\text { (B\&P) } \\
\text { - } & \text { Over current (OC) } \\
\text { - } & \text { Earth fault protection (EFP) } \\
\text { - } & \text { Differential protection (DP) } \\
\text { - } & \text { Outage of incomers (OI) } \\
\text { - } & \text { Bus bar protection (BBP) }\end{array}$ \\
\hline & Mechanical outage & $\begin{array}{ll}\text { - } & \text { Breakdown \& Damage } \\
\text { (B\&D)* } \\
\text { - } & \text { Fire Fighting System (FFS) } \\
\text { - } & \text { Hot spots (HS) } \\
\text { - } & \text { Oil, Air or SF6 leakage } \\
\end{array}$ \\
\hline & $\begin{array}{c}\text { Environmental } \\
\text { outage }\end{array}$ & $\begin{array}{ll}\text { - } & \text { Bad weather (BW) } \\
\text { - } & \text { Animal \& birds (A\&B) } \\
\end{array}$ \\
\hline & Others outage & $\begin{array}{ll}\text { - } & \text { No Flags (NF) } \\
\text { - } & \text { Others } \\
\end{array}$ \\
\hline$\cdot \frac{\grave{a}}{\bar{\pi}}$ & $\begin{array}{ll}\text { - } & \text { Tap changer } \\
\text { - } & \text { Winding } \\
\text { - } & \text { Core } \\
\text { - } & \text { Bushing } \\
\text { - } & \text { Tank and Conse } \\
\text { - } & \text { Insulation deteri }\end{array}$ & $\begin{array}{l} \\
\text { tor } \\
\text { tion } \\
\end{array}$ \\
\hline
\end{tabular}

* B\&D include external equipment failures in transformer circuit (current $\&$ potential transformer, surge arrestor, etc.)

Surveys and reports put in evidence two main kinds of failure sources of transformer outages. Major failures, those that are severe and require the removal of transformer to be reprocessed under factory conditions or its replacement. Minor failures can be repair on site. An overall view on general outage causes of transformers, according to previous surveys, is shown in Table 1. The others outage causes are related to over flux tripping, circuit breaker failure, low oil level, etc.

This paper is organized as follows, in section II the qualitative and quantitative failure modes and effect analysis (FMEA and FMECA) is discussed, while in section III FMEA on power transformers is reported.

\section{FMECA}

IEC-60182 [10] defines FMEA as a systematic procedure for the analysis of a system which target is the identification of the potential failure modes, their causes and effects on system performance. It is a bottom up failure analysis method that highlights common failure causes of the system and provide a rank for each failure mode related to element importance. Additionally, it focuses on system parts and/or functions that are most likely to fail. MIL-Std-1629A [11] consideres the usefulness of the FMEA as a reliability tool during design phase for decision making process upon the effectiveness of system functional failures and problems information. On other hand, TM 5-698-4 standard [12] and ANSI/IEEE std. 352 [13] depict the importance of FMEA for safety analysis, maintainability plan analysis and failure detection.

FMEA should include a list of equipment failure modes, like that shown in table 1 , reasons of these failures, local effects that refer to the consequences of each possible failure on the system element, final effects that describe the impact of that possible failures on the whole system, an alternative provision or recommended corrective actions to avoid these failures [10], [11], [12], [13]. Finally, a critically analysis (CA) allowing to assign a Risk Priority Number (RPN) to each failure mode must be done:

$$
\mathrm{RPN}=S \times O \times D
$$

where $S$ (Severity) represents the severity on the base of the assessment of the worst potential consequences resulting from an item failure, $O$ (Occurrence) denotes the probability of failure mode occurrence and $D$ (Detection) represents the chance to identify and eliminate the failure before the system or customer is affected. Fig. 2 shows a schematic diagram of the necessary steps to carry out both FMEA and CA.

In this way the definition of RPN allows to introduce the criticality of outages (FMECA). The criteria for selecting severity, occurrence, and detection values depends on standards [10], [11], [12]. In this paper, an analysis based on IEC-60182 evaluation criteria, as shown in TABLE II. is applied to power transformers.

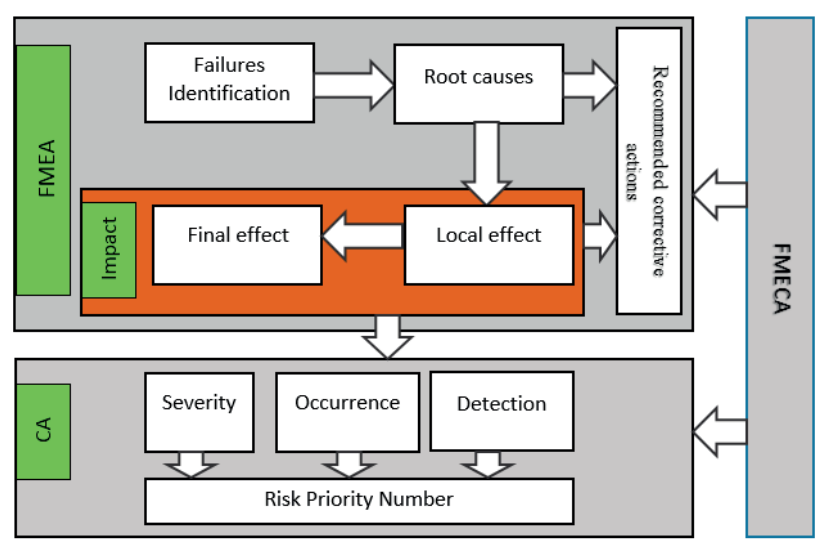

Fig. 2 Schematic Diagram of FMECA 


\begin{tabular}{|c|c|c|c|}
\hline Occurrence $(O)$ & Severity $(S)$ & Detection $(D)$ & Ranking \\
\hline Failure is unlikely & No discernible effect & Almost certain & 1 \\
\hline \multirow{2}{*}{$\begin{array}{c}\text { Low: } \\
\text { Relatively few failures }\end{array}$} & Very minor & Very high & 2 \\
\hline & Minor & High & 3 \\
\hline \multirow{3}{*}{$\begin{array}{c}\text { Moderate: } \\
\text { Occasional failures }\end{array}$} & Very low & Moderately high & 4 \\
\hline & Low & Moderate & 5 \\
\hline & Moderate & Low & 6 \\
\hline \multirow{2}{*}{$\begin{array}{c}\text { High: } \\
\text { Repeated Failures }\end{array}$} & High & Very low & 7 \\
\hline & Very high & Remote & 8 \\
\hline \multirow{2}{*}{$\begin{array}{l}\text { Very high: } \\
\text { Failure is almost unavoidable }\end{array}$} & Hazardous with warning & Very remote & 9 \\
\hline & Hazardous without warning & Absolutely uncertain & 10 \\
\hline
\end{tabular}

\section{FMECA FOR $220 \mathrm{KV}$ TRANSFORMERS}

The FMECA of functional/components minor and major failures of in-service transformers are estimated in Table III and Table IV respectively. In these tables attention is given to all possible major and minor failures that might result in interruption of transformer service. The impact of minor failures are not significant on transformer life. Therefore, the final effects of minor failures are interpreted in terms of transformer repair time duration. However, the frequent over current outages in the long run, resulting from overloading, lead to insulation degradation over time [14]. Also operation of Buchholz and pressure relief gives a strong indication to high percentage of combustion gases that are considered the catalyst agent for transformer ageing [15].

As reported in Table III overcurrent outages scores the highest RPN. Nowadays, the goal for the majority of transmission dispatch centers is the operation of transformers within IEC-60354 loading limit [16]. However, their ultimate challenge is the rapid growth of loads. Consequently, transformers are tripped frequently by overcurrent protection.

On other hand, earth fault and differential protection have the same high RPN. Their occurrence represent a hazard for the transformer operation. Generally, the low voltage side of $220 \mathrm{kV}$ transformers feed medium level transformers, $132 \mathrm{kV}$, $66 \mathrm{kV}$, or 33 $\mathrm{kV}$, and they are quite far from the unbalance in the distribution system. Therefore, the activation of earth fault protection in $220 \mathrm{kV}$ requires more attention and investigation for recognizing the fault nature. The differential protection operates if there is a disturbance in the protection zone, its operation gives a strong indication to utilities for a serious hazard within this zone. This will require site tests for the transformer including gas analysis. Buchholz and pressure relief are utterly similar to differential protection, its protective zone is limited to the transformer body.

Outage of incomers is a source of disturbance for utilities network operation, these outages occur frequently in transmission networks that have limited generation capabilities. It is associated with the disappearance of voltage from the $220 \mathrm{kV}$ busbar. This will force the transmission utility to disconnect the transformer from both sides and reconnect it again.

Table IV assigned the highest RPN in transformer major failures to insulation deterioration and on-load tap changer respectively. Insulation deterioration is an irreversible phenomena associated with transformers in service that results from oxygen, moisture and temperature. Moreover, it is considered the major reason of transformer failures before reaching their designed expected life [17]. Tap changer is the only moveable element in the transformer, and had been prone to a range of failures associated with the switching contacts and drive mechanism. Therefore, the condition of the tap changer oil and its contacts resistance are the most encountered problems to power utilities [18]. Nowadays, large number of utilities mount filter units externally on the tap changer compartment. However, these units reduce the filtration periods of the oil but don't give a clear view on the state of the switching contacts. Thus, the contacts degradation and mechanical defects can remain undetected.

Core and windings failures are the most catastrophic scenarios of transformers outages, they require an immediate replacement of the transformer and, in case a spare transformer is not directly available, additional costs for not delivered power and penalty costs should also be considered. The frequency of their occurrence is very low but their impact on the network operation is extremely high. 
TABLE III. MINOR FAILURES FMECA OF TRANSFORMERS

\begin{tabular}{|c|c|c|c|c|c|c|c|c|c|}
\hline Failure & $\begin{array}{c}\text { Outage } \\
\text { mode }\end{array}$ & Possible outage cause & Local effect & Final effect & $\begin{array}{c}\text { Compensating provision } \\
\text { against failure }\end{array}$ & $\mathbf{S}$ & $\mathbf{O}$ & D & RPN \\
\hline \multirow{16}{*}{$\stackrel{\grave{\Xi}}{\dot{\Xi}}$} & B \& P & Internal arcs & $\begin{array}{c}\text { Excessive pressure and } \\
\text { combustion gases }\end{array}$ & $\begin{array}{l}\text { Long repair time \& long } \\
\text { term transformer ageing } \\
\end{array}$ & $\begin{array}{c}\text { Dissolved gas analysis } \\
\text { Condition monitoring }\end{array}$ & 5 & 5 & 2 & 50 \\
\hline & $\mathrm{OC}$ & $\begin{array}{l}\text { Overloading / External } \\
\text { faults }\end{array}$ & Thermal ageing & $\begin{array}{c}\text { Intermediate repair time } \\
\& \text { long term transformer } \\
\text { ageing }\end{array}$ & System monitoring & 6 & 6 & 2 & 72 \\
\hline & EFP & $\begin{array}{l}\text { Winding inter turn / core/ } \\
\text { external faults }\end{array}$ & Loss of power & Short repair time & System monitoring & 5 & 4 & 3 & 60 \\
\hline & DP & $\begin{array}{l}\text { Internal fault within the } \\
\text { protected region }\end{array}$ & Loss of power & Intermediate repair time & $\begin{array}{c}\text { Preventive maintenance of } \\
\text { transformer } \\
\text { switchgear/accessories }\end{array}$ & 5 & 4 & 3 & 60 \\
\hline & OI & $\begin{array}{c}\text { Voltage of HV bus bar } \\
\text { disappeared as a result of } \\
\text { power generation outages/ } \\
\text { faults at BB incomers }\end{array}$ & $\begin{array}{l}\text { Immediate shutdown of } \\
\text { transformer and loss of } \\
\text { power }\end{array}$ & Short repair time & System monitoring & 6 & 4 & 2 & 48 \\
\hline & BBP & $\begin{array}{c}\text { Internal fault within the } \\
\text { protected region }\end{array}$ & Power interruption & Short repair time & $\begin{array}{l}\text { Protection design and proper } \\
\text { setting of protection relays }\end{array}$ & 7 & 3 & 2 & 42 \\
\hline & B \& D & $\begin{array}{c}\text { Breakdown \& damage of } \\
\text { transformer/main circuit } \\
\text { HV equipment }\end{array}$ & $\begin{array}{c}\text { Power Interruption during } \\
\text { the replacement of } \\
\text { damaged equipment }\end{array}$ & Long repair time & $\begin{array}{c}\text { Preventive maintenance } \\
\text { through electrical tests to } \\
\text { check up insulation condition }\end{array}$ & 7 & 3 & 2 & 42 \\
\hline & FFS & $\begin{array}{c}\text { A real hazard or } \\
\text { malfunction in Firefighting } \\
\text { sensors/valves }\end{array}$ & $\begin{array}{l}\text { Power interruption for } \\
\text { real hazard, immediate } \\
\text { shut down of FFS for } \\
\text { malfunction }\end{array}$ & $\begin{array}{c}\text { Short repair time } \\
\text { ( FFS malfunctioning) }\end{array}$ & $\begin{array}{c}\text { Scheduled maintenance } \\
\text { program to check the valves } \\
\text { and sensor conditions, } \\
\text { pressure of air and water of } \\
\text { FF system }\end{array}$ & 2 & 3 & 3 & 18 \\
\hline & HS & Loose connections & $\begin{array}{l}\text { Overheating and power } \\
\text { losses }\end{array}$ & Short repair time & Thermal Image & 2 & 4 & 4 & 32 \\
\hline & Leakage & $\begin{array}{c}\text { Leakage of oil from main } \\
\text { tank/SF6 gas from GIS } \\
\text { compartment/ air from } \\
\text { Circuit breaker }\end{array}$ & $\begin{array}{c}\text { Low level of oil operates } \\
\text { buchholz relay/ circuit } \\
\text { breaker will be in blocked } \\
\text { state for Sf6 or air } \\
\text { leakage }\end{array}$ & Long repair time & $\begin{array}{c}\text { Periodic visual inspection of } \\
\text { pressure gauges }\end{array}$ & 2 & 4 & 3 & 24 \\
\hline & FO & Deposit of dirt on bushings & $\begin{array}{l}\text { Arcing and tracking } \\
\text { Of bushings }\end{array}$ & Intermediate repair time & $\begin{array}{c}\text { Periodic cleaning of } \\
\text { transformer tank and } \\
\text { bushings }\end{array}$ & 2 & 4 & 4 & 32 \\
\hline & BW & Wind and rains & $\begin{array}{c}\begin{array}{c}\text { Slippage of transformer } \\
\text { accessories and protection } \\
\text { devices }\end{array} \\
\end{array}$ & Intermediate repair time & $\begin{array}{c}\text { Checking the outdoor } \\
\text { protection wires /cables and } \\
\text { clearance distances }\end{array}$ & 4 & 3 & 2 & 24 \\
\hline & $\mathrm{A} \& \mathrm{~B}$ & $\begin{array}{c}\text { Crossing the magnetic field } \\
\text { of the transformer }\end{array}$ & $\begin{array}{l}\text { Phase to phase or phase } \\
\text { to ground faults }\end{array}$ & Intermediate repair time & $\begin{array}{l}\text { Caging outdoor visible } \\
\text { connections }\end{array}$ & 4 & 3 & 2 & 24 \\
\hline & $\mathrm{HM}$ & $\begin{array}{c}\text { Wrong switching, } \\
\text { intervening actions within } \\
\text { transformer magnetic field }\end{array}$ & $\begin{array}{c}\text { Human injury risk, loss of } \\
\text { power }\end{array}$ & Short repair time & $\begin{array}{c}\text { Following up a firmly safety } \\
\text { rules }\end{array}$ & 7 & 3 & 2 & 42 \\
\hline & NF & $\begin{array}{l}\text { No alarm or indication to } \\
\text { transformer outage }\end{array}$ & $\begin{array}{l}\text { Overloading risk on } \\
\text { nearby parallel } \\
\text { transformer }\end{array}$ & $\begin{array}{c}\text { Intermediate repair time } \\
\text { for investigating the } \\
\text { exact outage reason }\end{array}$ & $\begin{array}{l}\text { Considering the design of } \\
\text { protection \& alarm system }\end{array}$ & 3 & 3 & 4 & 36 \\
\hline & Others & $\begin{array}{l}\text { Malfunction of circuit } \\
\text { breakers, over flux } \\
\text { protection, abnormal } \\
\text { sounds of operation, tap } \\
\text { changer control, etc. }\end{array}$ & Loss of power & High repair time & $\begin{array}{c}\text { Preventive maintenance of } \\
\text { transformer } \\
\text { switchgear/accessories }\end{array}$ & 3 & 5 & 3 & 45 \\
\hline
\end{tabular}


TABLE IV. MAJOR FAILURES FMECA OF TRANSFORMERS

\begin{tabular}{|c|c|c|c|c|c|c|c|c|c|}
\hline Failure & $\begin{array}{l}\text { Outage } \\
\text { mode }\end{array}$ & $\begin{array}{c}\text { Possible outage } \\
\text { cause }\end{array}$ & Local effect & Final effect & $\begin{array}{c}\text { Compensating provision } \\
\text { against failure }\end{array}$ & $\mathbf{S}$ & $\mathbf{O}$ & D & RPN \\
\hline \multirow{6}{*}{$\stackrel{\bar{a}}{\frac{\operatorname{ag}}{2}}$} & $\begin{array}{l}\text { On-load } \\
\text { tap changer }\end{array}$ & $\begin{array}{l}\text { Wearing out of } \\
\text { selector contact, } \\
\text { loose base, loose } \\
\text { spring, low } \\
\text { insulation of oil }\end{array}$ & $\begin{array}{l}\text { Arcs and partial } \\
\text { discharges inside } \\
\text { tap. Overheating } \\
\text { and excessive } \\
\text { pressure }\end{array}$ & $\begin{array}{c}\text { Replacement of } \\
\text { tap changer and } \\
\text { loss of power }\end{array}$ & $\begin{array}{c}\text { Preventive maintenance } \\
\text { based on regular periods or } \\
\text { number of tap changer } \\
\text { operations. } \\
\text { Online oil filtration. }\end{array}$ & 7 & 4 & 7 & 196 \\
\hline & Winding & $\begin{array}{l}\text { Continuous } \\
\text { Overloading, } \\
\text { moisture } \\
\text { contents, sludge, } \\
\text { oxidation }\end{array}$ & $\begin{array}{l}\text { Thermal and } \\
\text { mechanical } \\
\text { ageing of } \\
\text { winding. } \\
\text { Incapability to } \\
\text { stand future short } \\
\text { circuits }\end{array}$ & $\begin{array}{l}\text { Transformer } \\
\text { ageing, and } \\
\text { replacement of } \\
\text { transformer }\end{array}$ & $\begin{array}{c}\text { Mechanical and Electrical } \\
\text { condition assessment } \\
\text { (SFRA, DC resistance of } \\
\text { winding, turns ratio, } \\
\text { Meggar) }\end{array}$ & 9 & 2 & 9 & 162 \\
\hline & Core & $\begin{array}{l}\text { Rust deposits, } \\
\text { excessive heating } \\
\text { or burning of the } \\
\text { laminations } \\
\text { insulation }\end{array}$ & $\begin{array}{l}\text { Hot spot, high } \\
\text { losses as a result } \\
\text { of eddy current } \\
\text { and flux } \\
\text { distortion }\end{array}$ & $\begin{array}{l}\text { Transformer } \\
\text { ageing. } \\
\text { Replacement of } \\
\text { transformer }\end{array}$ & $\begin{array}{c}\text { Condition monitoring } \\
\text { through Dissolved gas } \\
\text { analysis, oil and furan } \\
\text { analysis. }\end{array}$ & 9 & 2 & 9 & 162 \\
\hline & $\begin{array}{l}\text { Oil-Filled } \\
\text { Bushings }\end{array}$ & $\begin{array}{l}\text { Moisture from } \\
\text { leaky gaskets. } \\
\text { Gas bubbles } \\
\text { from prolonged } \\
\text { exposure to } \\
\text { extreme } \\
\text { electrical, } \\
\text { mechanical and } \\
\text { environmental } \\
\text { conditions. }\end{array}$ & $\begin{array}{l}\text { Conducting } \\
\text { tracks that can } \\
\text { short out one or } \\
\text { more layers of } \\
\text { the bushing. }\end{array}$ & $\begin{array}{l}\text { Bushing/ } \\
\text { gasket } \\
\text { replacement }\end{array}$ & $\begin{array}{l}\text { Thermal image and } \\
\text { bushing tan delta, } \\
\text { capacitance monitoring. } \\
\text { Periodic inspection of oil } \\
\text { level of the busing window }\end{array}$ & 6 & 2 & 7 & 84 \\
\hline & Tank & $\begin{array}{l}\text { Tank rupture as a } \\
\text { result of severe } \\
\text { short circuit and } \\
\text { malfunction in } \\
\text { protection system }\end{array}$ & $\begin{array}{l}\text { Transformer } \\
\text { replacement }\end{array}$ & Loss of power & $\begin{array}{l}\text { Regular testing of } \\
\text { protection systems }\end{array}$ & 9 & 2 & 3 & 54 \\
\hline & $\begin{array}{c}\text { Insulation } \\
\text { deterioration }\end{array}$ & $\begin{array}{l}\text { Oxidation, high } \\
\text { acidity, low } \\
\text { breakdown of oil, } \\
\text { moisture of } \\
\text { windings paper }\end{array}$ & $\begin{array}{c}\text { High arcing, } \\
\text { corona, and } \\
\text { partial discharge }\end{array}$ & $\begin{array}{l}\text { Oil filtration / } \\
\text { oil replacement } \\
\text { in site, or } \\
\text { reprocessing of } \\
\text { insulation } \\
\text { condition in } \\
\text { factory }\end{array}$ & $\begin{array}{c}\text { Dissolved gas analysis } \\
\text { monitoring, Furan test, tan } \\
\text { delta of oil, and chemical } \\
\text { analysis of oil } \\
\text { characteristics }\end{array}$ & 8 & 4 & 8 & 256 \\
\hline
\end{tabular}

\section{CONCLUSIONS}

The aim of presenting a FMECA on utility transformers is to provide power utilities a guide of feasible hazards that could interrupt transformers operation and result in financial losses. FMECA risk priority number depends on many factors and varies according to the operating and environmental condition of power utilities. We tried to generalize the severity, occurrence and detection of the $220 \mathrm{kV}$ transformer failures for a better performance in the transmission network.

\section{REFERENCES}

[1] IEEE Guide for Reporting Failure Data for Power Transformers and Shunt Reactors on Electric Utility Power Systems. 1986.

[2] An international survey on failures in large power transformers in service, Final Report of Working Group 05 of Study Committee 12, Electra, 88, May 1983.

[3] MSA Minhas, JP Reynders, and PJ de klerk, "Failure in power system transformers and appropriate monitoring techniques," presented at the 11th International Symposium on High Voltage Engineering, London, U.K., 1999

[4] J.N. Jagers, J. Khosa, P.J. De Klerk, and C.T. Gaunt," Transformer Reliability and Condition Assessment in a South African Utility, "presented in XV International Symposium on High Voltage Engineering, Ljubljana, Slovenia, August 2007.

[5] Dietermann T, Balzer G, Neumann C. The development in electricity exchanges and their impact on the German transmission system. In: Proceedings of the power tech, Lausanne, Switzerland; 2007. p. 12-6

[6] European Network of Transmission System of Electricity, TEN-YEAR NETWORK DEVELOPMENT PLAN 2010-2020, final report 2010. Available on www.entsoe.eu

[7] J. Jansen, "EHV lines in the Federal Republic of Germany," IEEE Spectrum, 7 (4) (2009), pp. 33-40

[8] Mateescu, E.; Marginean, D.; Florea, G.; Gal, S.I.A.; Matea, C., "Reconductoring using HTLS conductors. Case study for a $220 \mathrm{kV}$ double circuit transmission LINE in Romania," Transmission and Distribution Construction, Operation and Live-Line Maintenance (ESMO), 2011 IEEE PES 12th International Conference, pp.1-7, May 2011.

[9] M. Abdelfatah, M. EL-Shimy, and H. M. Ismail, "Reliability and maintainability analysis of medium voltage transformers in Egypt," in 8th 
International Conference on Electrical Engineering ICEENG-8, Cairo, Egypt, 2012

[10] IEC-60182, Analysis techniques for system reliability- Procedure for failure mode and effects analysis (FMEA), 2006.

[11] MIL-STD-1629A, Procedures for Performing a Failure Mode, Effects and Criticality Analysis, Nov. 1980.

[12] Department of the Army, TM 5-698-4, Failure Modes, Effects and Criticality Analyses (FMECA) for Command, Control, Communications, Computer, Intelligence, Surveillance, and Reconnaissance (C4ISR) Facilities, 29 September 2006.

[13] IEEE guide for general principles of reliability analysis of nuclear power generating station protection systems, ANSI/IEEE std. 352, 1987.

[14] Sen, P.K.; Sarunpong Pansuwan, "Overloading and loss-of-life assessment guidelines of oil-cooled transformers," Rural Electric Power Conference, 2001, pp.B4/1-B4/8, 2001

[15] IEEE Guide for the Interpretation of Gases Generated in Oil-Immersed Transformers," IEEE Std. C57.104-2008 (Revision of IEEE Std. C57.104-1991), pp.1-36, 2009.

[16] IEC-60354, loading guide for oil-immersed power transformers, 2nd edition, 1991.

[17] Arshad, M.; Islam, S.M., "Significance of cellulose power transformer condition assessment," Dielectrics and Electrical Insulation, vol.18, no.5, pp.1591-1598, October 2011

[18] Jauch, E.T., "How Tapchanger Controls Contribute to Premature Transformer Failures," Power Engineering Society General Meeting, pp.1-5, June 2007.
[19] R. Jongen, Peter Morshuis, E. Gulski, and J. Smit, "Statistical analysis of power transformer component life time, " in Proc. 8th International Power Eng. Conf. (IPEC 2007), Singapore, 2007, pp. 1273-1277.

[20] Thanapong Suwanasri, Ekkachai Chaidee, and Cattareeya Adsoongnoen, "Failure statistics and power transformer condition evaluation by dissolved gas analysis technique," in international Conference on Condition Monitoring and Diagnosis, Beijing, China, 2008.

[21] M. Abdelfatah, M. EL-Shimy, and H. M. Ismail, "Outage data analysis of utility power transformers based on outage reports during 2002-2009," in International Journal of Electrical Power \& Energy Systems, Volume 47, pp. 41-51, May 2013.

[22] M. EL-Shimy, M. Abdelfatah, and H. M. Ismail, "Reliability, Availability, and Maintainability (RAM) Analysis of Utility Power Transformers," in ELEKTRIKA- UTM Journal of Electrical Engineering, Vol. 14, No 1 (2012).

[23] M. Abdelfatah, M. EL-Shimy, and H. M. Ismail, "Performance analysis of protective devices for power transformers in Egypt," in 8th International Conference on Electrical Engineering ICEENG-8, Cairo, Egypt, 2012.

[24] Renaud, F., "220 kV gas-insulated transmission line-Palexpo Geneva Switzerland," Power Engineering Society General Meeting, 2003, IEEE, vol.4, no., pp.,2479 Vol. 4, 13-17 July 2003.

[25] Borucki, S.; Boczar, T.; Fracz, P.; Zmarzly, D., "Diagnostics of power transformers cores using a modified vibroacoustic method," Electrical Insulation (ISEI), Conference Record of the 2012 IEEE International Symposium, pp.179-183, 10-13 June 2012 